\title{
Znikający powojenny modernizm - czy prawo powinno szerzej chronić dobra kultury?
}

\section{JEL Classification: K19}

Słowa kluczowe: architektura, późny modernizm, ochrona zabytków

Keywords: architecture, late modernism, protection of monuments

\begin{abstract}
Abstrakt: Celem artykułu jest przybliżenie problemu wyburzania cennych obiektów architektury modernistycznej oraz postawienie pytania o potrzebę i zakres ich ochrony. Autorka analizuje wymogi ustawy o ochronie zabytków i opiece nad zabytkami, co w konsekwencji prowadzi do stwierdzenia, że w wypadku obiektów architektury modernistycznej niezbędne jest wprowadzenie nowych, skutecznych środków ochrony oraz ustalenie odpowiednich kryteriów oceny i wartościowania. Autorka omawia wybrane przykłady wyburzonych już dzieł, wskazując cechy świadczące o ich wyjątkowości, a także przeprowadza analizę porównawczą względem obiektów stawianych w ich miejsce. W związku z wyburzeniem większości budynków powojennego modernizmu, powodowanym brakiem skutecznych działań służb konserwatorskich, autorka wnosi postulat większego udziału krytyków architektury przy kwalifikacji obiektu do objęcia go ochroną.
\end{abstract}

\section{The disappearance of late modernism - shall the scope of the law's protection of monuments be broader?}

\begin{abstract}
The aim of the article is to analyze the problem of demolishing valuable objects of modernist architecture. It raises a question of the scope of protection needed. The author analyzes the requirements of the legal statutes, which leads to the conclusion that there is indeed a great need for new and effective protection measures, as well as the establishment of appropriate evaluation criteria. The author discusses certain examples of demolished buildings, pointing out the features that made them unique and exceptional. Moreover, the article compares those "never recognized nor acknowledged" monuments with the buildings which has taken their space. Due to the fact, that the demolition of the most of the post-war modernism buildings happened because of the lack of appropriate and effective conservation efforts, the author calls for greater involvement of architectural critics in the process of qualification of monuments and their protection.
\end{abstract}


Środowiska intelektualne, artystyczne, naukowe i zawodowe architektów oraz urbanistów od lat pracują nad skuteczną ochroną dla powojennej architektury. Generalna konserwator zabytków na Ogólnopolskiej Konferencji „Ochrona dziedzictwa architektury i urbanistyki polskiej drugiej połowy XX wieku" powiedziała, że:

Powinniśmy chronić dla przyszłych pokoleń to, co najcenniejsze z obiektów powojennej architektury, będącej wyrazem naszej nowoczesności. Nie powinniśmy dopuścić do tandetnej modernizacji Polski. Potrzebne jest określenie zasad i reguł ochrony tej architektury, aby nie dopuścić do dowolności w jej adaptacji, poprzez niewłaściwą przebudowę ${ }^{1}$.

Ze względu na trudną sytuację polityczną i gospodarczą powojenna rzeczywistość stanowiła nie lada wyzwanie dla ówczesnych architektów — wszakże Polska miała odrodzić się niczym „feniks z popiołów”. Pomimo trudności architektura, jaka wtedy powstawała, jest wyrazem kontynuacji nowoczesnych nurtów europejskich, lecz także eksploracji awangardowych rozwiązań przestrzennych ${ }^{2}$. W uchwale nr 1 z dnia 29 kwietnia 2016 roku $^{3}$ Rada Ochrony Zabytków postulowała stworzenie listy obiektów drugiej połowy XX w. przeznaczonych do objęcia ochroną, zwracając się tym samym do środowisk twórczych i naukowych o opinię i pomoc. Jej celem jest ,zainicjowanie procesu interpretacji, waloryzacji zasobu, określenia granic interwencji i stosownych form ochrony, która jest naszym prawem i obowiązkiem"4.

Dzisiaj niestety zbyt często obiekty modernistyczne traktuje się jako przedmioty, nie zważywszy na ich podłoże konceptualne ${ }^{5}$, stanowiące niewątpliwą wartość. Zdaniem Mariusza Ścisło konieczne jest zatem stworzenie modelu współczesnej ochrony dziedzictwa, polegającego w szczególności na zamianie kryterium „zabytku” na pojęcie „dziedzictwa”. Wszakże, o ile zabytek związany jest z przeszłością, o tyle dziedzictwo sprzyja także obecnym, współczesnym celom ${ }^{6}$.

${ }^{1}$ M. Gawin, Konferencja o ochronie dziedzictwa architektury i urbanistyki, 17.11.2016 r., http:// mkidn.gov.pl/pages/posts/konferencja-o-ochronie-dziedzictwa-architektury-i-urbanistyki-6841. php (dostęp: 15.07.2017).

2 Uchwała nr 1 RADY OCHRONY ZABYTKÓW przy Ministrze Kultury i Dziedzictwa Narodowego w sprawie ochrony dziedzictwa architektury i urbanistyki XX wieku w Polsce z dnia 29 kwietnia 2016 roku, „Mazowiecki Wojewódzki Konserwator Zabytków” dotyczące relacji z panelu o modernizmie, http://konserwacja.pk.edu.pl/archXXpl/ (dostęp: 15.07.2017).

${ }^{3}$ Ibidem.

${ }^{4}$ Materiał zamieszczony na stronie „Mazowiecki Wojewódzki Konserwator Zabytków” dotyczący relacji z panelu o moderniźmie, http://www.mwkz.pl/archiwum-aktualnosci-lista/1015-fotorelacja-z-panelu-o-modernizmie (dostęp: 15.07.2017).

5 J.T. Królikowski, Modernizm warszawski po 1955. Zdobywanie i odzyskiwanie form. Referat, Katedra Sztuki Krajobrazu SGGW, Warszawa 2016.

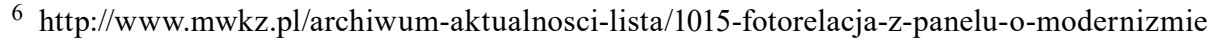
(dostęp: 15.07.2017). 
Powszechnie razi nieskuteczność w obszarze ochrony obiektów powojennego modernizmu, spowodowana brakiem spójności w zapisach poszczególnych przepisów prawa ${ }^{7}$ : ustawy o ochronie i opiece nad zabytkami ${ }^{8}$, ustawy o prawie budowlanym ${ }^{9}$ oraz ustawy o zagospodarowaniu i planowaniu przestrzennym ${ }^{10}$. W konsekwencji wiele polskich ikon architektury modernistycznej zostało już doszczętnie zniszczonych, utraciliśmy najlepszych reprezentantów swego czasu, technologii i architektury, jak również obiekty endemicznie wyjątkowe. W związku z powyższym należy podjąć działania powstrzymujące proces destrukcji obiektów wartych zachowania dla przyszłych pokoleń, nie dopuszczając do wyburzeń kolejnych dzieł, które mogłyby stanowić wzorzec rozwiązań dla wielu budynków powstających współcześnie. Warto również zwrócić uwagę, że ochrona prawna to tylko teoretyczna część ochrony powojennego modernizmu. Istotny aspekt opieki stanowi praktyka remontowa, rewitalizacyjna i konserwatorska ${ }^{11}$, lecz także zmiana świadomości społeczeństwa, w tym właścicieli, inwestorów i zarządców tego typu obiektów, przeprowadzona dzięki pogłębieniu edukacji społecznej z zakresu powojennej architektury.

Celem niniejszej pracy jest próba odpowiedzi na pytanie o potrzebę i zakres systemowej ochrony powstałych po 1945 r. dzieł techniki i architektury stanowiących dziedzictwo kulturowe - na wzór ochrony, jaką objęte zostały dzieła z wcześniejszych epok historycznych.

\section{Jak chronić?}

Obowiązująca ustawa o ochronie zabytków i opiece nad zabytkami umożliwia różne formy ochrony, takie jak: uznanie obiektu za pomnik historii, wpis do rejestru zabytków, ujęcie w ewidencji zabytków, ustalenie ochrony w planie miejscowym lub utworzenie parku kulturowego. W praktyce jednak najbardziej skuteczną formą ochrony prawnej pozostaje umieszczenie obiektu w rejestrze zabytków ${ }^{12}$.

Zgodnie $\mathrm{z}$ art. 3 ustawy o ochronie zabytków i opiece nad zabytkami ${ }^{13}$ miano zabytku otrzymuje obiekt stanowiący „dzieło człowieka” lub „związany z jego działalnością”, będący jednocześnie „świadectwem minionej epoki” bądź zdarze-

\section{Ibidem.}

8 Ustawa z dnia 23 lipca 2003 r. o ochronie zabytków i opiece nad zabytkami (Dz.U. z 2003 r. Nr 162, poz. 1568).

9 Ustawa z dnia 7 lipca 1994 r. — Prawo budowlane (Dz.U. z 1994 r. Nr 89, poz. 414).

10 Ustawa z dnia 27 marca 2003 r. o planowaniu i zagospodarowaniu przestrzennym (Dz.U. z 2003 r. Nr 80, poz. 717).

11 http://www.mwkz.pl/archiwum-aktualnosci-lista/1015-fotorelacja-z-panelu-o-modernizmie (dostęp: 15.07.2017).

12 M. Gawlicki, Rejestr zabytków w praktyce ochrony konserwatorskiej, „Ochrona Zabytków” 2008, nr 2, s. 55-82.

13 Dz.U. z 2003 r. Nr 162, poz. 1568. 
nia, którego „zachowanie leży w interesie społecznym ze względu na posiadaną wartość historyczną, artystyczną lub naukową". Należy zauważyć, że ustawa nie wdraża standardów, które w sposób jednoznaczny i pozbawiony subiektywnych interpretacji rozstrzygałyby o wartościach poszczególnych obiektów. Nie wymienia również kryterium autentyczności i wartości materialnej obiektu. Co więcej, nie definiuje ,interesu społecznego", doprowadzając tym samym do wielu wątpliwości natury interpretacyjnej. Świadczy to o niejasnych kryteriach i przypadkowych, dyskrecjonalnych ocenach ${ }^{14}$. Nie ulega zatem wątpliwości, że ustawa pozostawia również istotne luki w zakresie podstawowych informacji o rejestrze i ewidencji zabytków. Wszelkie ewaluacje uzależnione są od indywidualnych interpretacji wojewódzkich konserwatorów zabytków, do których każdorazowo należy decyzja o wpisie obiektu do rejestru zabytków.

Można by przypuszczać, że wartościowanie obiektów architektonicznych cechuje rutynowy, schematyczny i intuicyjny charakter ${ }^{15}$, co stanowi w dziedzinie architektury istotny problem związany z kwestią zdatności obiektu do zostania objętym ochroną konserwatorską. Po pierwsze, istotną kwestią jest ustalenie, czy wartościowanie uwzględnia spectrum wartości najodpowiedniejsze dla konkretnego przy padku. Po drugie, należy przyjąć, że wartościowanie dokonywane w obrębie danej kategorii obiektów powinno opierać się na konkretnym ustalonym dla niej systemie wartości, uporządkowanym według stopnia ważności ${ }^{16}$. Po trzecie, wartościowanie związane jest $\mathrm{z}$ oceną zmienną w czasie i uzależnioną od wielu czynników zewnętrznych, co wydaje się szczególnie istotne w wypadku rozpatrywania obiektów architektury modernistycznej.

Mając powyższe na względzie, celem nadrzędnym powinno być wprowadzenie nowych, prawnych środków ochrony obiektów architektury modernizmu, ustalenie odpowiednich kryteriów wartościowania architektury oraz wypracowanie w tym celu zasad współpracy architektów i służb konserwatorskich ${ }^{17}$. Szczególnym ułatwieniem związanym z ochroną obiektów modernistycznych może być dokładne wskazanie elementów ochrony, zakresu prac modernizacyjnych oraz określenie możliwości adaptacji i rozbudowy bryły, detalu czy wnętrza ${ }^{18}$. Wymaga to jednakże precyzyjnych badań i ekspertyz poszczególnych dzieł późnego modernizmu, co w praktyce napotyka na przeróżne bariery, skutecznie utrudnia-

14 M. Gawlicki, Ocena wartości zasobu zabytkowego - cele, metody, praktyka, Polski Komitet Narodowy ICOMOS, Warszawa 2013, s. 100.

15 B. Szmygin, Propozycje założeń do systemu wartościowania zabytków architektury — podmiot, przedmiot, status wartości, Polski Komitet Narodowy ICOMOS, Muzeum Pałac w Wilanowie, Warszawa 2013, s. 188.

16 Ibidem.

$17 \mathrm{http} / /$ www.mwkz.pl/archiwum-aktualnosci-lista/1015-fotorelacja-z-panelu-o-modernizmie (dostęp: 15.07.2017).

18 Ibidem. 
jące efektywną politykę konserwatorską. Podstawowy problem polega na istotnej różnicy interesów pomiędzy inwestorami a obrońcami dziedzictwa kultury.

Należy zauważyć, że dzieła powstałe po 1945 roku stanowią nasze narodowe dziedzictwo kulturowe i powinny być w związku z tym objęte systemową ochroną. W przypadku choćby obiektów powstałych w latach 30 . ubiegłego stulecia, objęcie ich ochroną konserwatorską poprzez wpis do rejestru zabyków nastąpiło już w latach 60. i 70., czyli po upływie niespełna 40 lat, od ich powstania. Warto przywołać tu słowa Magdaleny Gawin, która stwierdziła:

obecnie wybrane dzieła powojennego modernizmu, o ile stanowią świadectwo minionej epoki i spełniają kryteria wartości artystycznej, historycznej i naukowej, powinny być objęte taką samą ochroną konserwatorską, jak obiekty z lat międzywojennych ${ }^{19}$.

\section{Tytułem przypomnienia}

Modernizm rozwinął się, wypełniając lukę pozostawioną przez zdziesiątkowaną wojennymi działaniami architekturę neostylów. Zgodnie z ideowymi zasadami Le Corbusiera modernizm miał przywrócić elitarne prawa klasycznej geometrii jako podstawy ładu w życiu i architekturze. Architekt ten twierdził, że ,architektura polega na ustanawianiu poruszających relacji przy użyciu podstawowych materiałów" ${ }^{20}$. Istotne było więc tworzenie prostych form, projektowanych w oparciu o właściwe ich rozmieszczenie w planie, bryle i na powierzchni. Le Corbusier wprowadził również koncepcję pt. „zacząć od początku”. W Polsce po II wojnie światowej wymóg ten realizowany był w sposób aż nadto dosłowny. Budynki powstające w myśl ideowych zasad modernizmu budziły podziw i uznawane były za ze wszech miar nowatorskie. Celowym było wykraczanie poza ramy użyteczności ${ }^{21}$, architektura miała poruszać zmysły i zaspokajać wizualne pragnienia ludności ${ }^{22}$. Jej estetyka wynikała z zastosowania nieznanych wcześniej materiałów i nowatorskich sposobów ich użycia, funkcjonalnego ukształtowania budynku, tudzież nowej filozofii formy. Unikatowy charakter tworzyły szczegóły — jakość i faktura tynku, głębokość wnęk okiennych, detale w postaci metalowych masztów, kamiennych parapetów, balustrad, rozmaitych balkoników ${ }^{23}$. Tak zwany Ruch Nowoczesny cechował się więc oryginalnością i autentycznością.

19 M. Gawin, Panel konserwatorsko-architektoniczny...

20 Le Corbusier, W stronę architektury, Warszawa 2012, s. 186.

${ }^{21}$ Ibidem.

22 Ibidem, s. 71.

23 B. Ciarkowski, Kryterium autentyczności a wartościowanie zabytków architektury modernistycznej, Polski Komitet Narodowy ICOMOS, Muzeum Pałac w Wilanowie, Warszawa 2013, s. 72. 
Warto podkreślić, że późny modernizm postrzegany był zarówno jako wyraz nowoczesności, jak i kontynuacja pewnych wątków polskiej architektury ${ }^{24}$. Niezmiernie ważna $\mathrm{w}$ tym okresie była koncepcja przestrzeni, która wpłynęła na utworzenie idei formy otwartej, umożliwiającej odniesienie architektury nie tylko do kontekstu krajobrazowego, lecz także do kontekstu społecznego ${ }^{25}$. Wynika z tego, że dorobek modernizmu należałoby traktować jako pewną spójną, komplementarną całość. Warto zwrócić uwagę, że obecny kult swobody, kontestując wszelkie te koncepcje, eliminuje tym samym nieliczne, ocalałe „perełki” późnego modernizmu.

\section{Reductio ad absurdum: trwać albo runąć}

W latach 1945-1956 w Polsce obowiązywała doktryna „realizmu socjalistycznego", która objęła wszystkie dziedziny sztuki, w szczególności architekturę. Podstawą dla niej był referat Edmunda Goldzamta Zagadnienia realizmu socjalistycznego w architekturze, który wyznaczył obowiązującą wtedy na lata „,metodę twórczą"26. Zgodnie z nią architektura miała przekazywać treści socjalistyczne oraz kształtować idee światopoglądowe. Budowle miały wzbudzać poczucie siły państwa, jego demokratyzmu i humanizmu. Postępujący regres socrealizmu, poddawany licznej krytyce, doprowadził do rozmycia tej doktryny w $1956 \mathrm{r}^{27}$ Wciąż trudna sytuacja ekonomiczna stanowiła barierę do tworzenia i realizacji wielkich dzieł architektury, które wymagały ogromnych nakładów finansowych. Nie powstrzymało to jednakże chęci tworzenia nowatorskich obiektów, w tym np. istniejącej do dzisiaj katowickiej Hali Spodek. Obiekt ten ma dach zrealizowany w koncepcji tensegrity ${ }^{28}$ — fakt ten stanowi niewątpliwy dowód na rozwijające się w tamtym okresie innowacyjne metody konstrukcyjne.

Koncepcja ta zrealizowana była także wcześniej, przy budowie dachu warszawskiego pawilonu „Supersam”, zaprojektowanego przez zespół kierowany przez Macieja Krasińskiego (Ewę Krasińską i Jerzego Hryniewieckiego), o konstrukcji opracowanej przez Wacława Zalewskiego i Andrzeja Żórawskiego (projekt 1953 r., realizacja 1959-1962) ${ }^{29}$. Wisząca na stalowych naciągniętych linach i wsparta

24 J.T. Królikowski, op. cit.

25 Ibidem.

26 E. Goldzamt, Zagadnienie realizmu socjalistycznego w architekturze, [w:] O polska architekture socjalistyczna, Warszawa 1950, s. 15-47.

27 Ł. Kołodziejczyk, Doktryna realizmu socjalistycznego, http://www.nh.pl/socrealizm.htm (dostęp: 18.07.2017).

28 M. Pelczarski, O ksztaltowaniu konstrukcji dachu katowickiej hali Spodka. Rozważania z wywiadów z Profesorem Wacławem Zalewskim, „Architectus” 17, 2013, nr 2 (34), s. 69-82.

${ }_{29}$ M. Urbańska, Polska architektura późnego modernizmu - kategorie stanu zachowania, syntetyczne studia przypadków i dylematy konserwacji, „Wiadomości Konserwatorskie — Journal of Heritage Conservation" 2016, nr 48, s. 57. 
przemiennie na słupach rozpierających i odciągach konstrukcja umożliwiła zbudowanie ugiętego dachu, który zapewniał dużą powierzchnię użytkową bez podpór $^{30}$. Ekspresja tego wiszącego linowego dachu robi wrażenie do dziś, niestety już tylko poprzez utrwalenia archiwalne ${ }^{31}$. Destrukcja „Supersamu”, mająca miejsce w 2006 r., stanowiła symboliczny upadek architektury awangardowej, tym bardziej że pomimo licznych inicjatyw budynek nie został nigdy odtworzony ${ }^{32}$ i ustąpił jedynie miejsca nowej galerii biurowo-handlowej o nazwie „Plac Unii”.

Podobna sytuacja miała miejsce w wypadku nieistniejącego już pawilonu „Chemia” (Warszawa). Zaprojektowany przez Jana Bogusławskiego budynek handlowy, pomimo licznych protestów odnośnie do jego wyburzenia, nie przetrwał próby czasu $^{33}$. Jego lekka, przejrzysta forma zdecydowanie wyróżniała się na tle innych obiektów. Przez wiele lat pawilon był zaniedbywany - nie było kontroli stanu zachowania, a nieustannie zwiększająca się liczba reklam i tablic doprowadziła do zatarcia jego nowatorskiego, zjawiskowego wyglądu. Pomimo wpisania go na listę dóbr kultury współczesnej przez Stowarzyszenie Architektów Polskich ${ }^{34}$ obecnie na jego miejscu stoi dom handlowy Wolf Bracka. Dawniej lumpeks, dzisiaj ekskluzywna galeria. Wydawać by się mogło, że funkcja pozostała taka sama. Zarówno wcześniej, jak i teraz wyróżnia się na tle otaczających go budynków.

Pod rozwagę należy poddać jednak zastosowanie sporej kubatury nowego budynku, który ogranicza dostęp do światła mieszkańcom pobliskich bloków. Można by wręcz rzec, że obiekt zupełnie odbiega od zasad, którym hołdował pawilon „Chemii”. Celem architektury modernistycznej było bowiem zapewnienie dostępu do naturalnego światła, powietrza i zieleni zarówno proletariuszom, robotnikom, jak i inteligentom. Warto zauważyć, że wcześniejszy budynek spełniał tę rolę, zachowując tym samym dużą wartość estetyczną. Niewidoczna z zewnątrz, ciekawa konstrukcja pozwalała na doświetlenie wnętrza parteru naturalnym światłem słonecznym. Elewacja, którą tworzyły duże szyby wystawowe, spełniała natomiast założenia architektury „transparentnej” ${ }^{35}$. Warto zauważyć, że pawilon ten był atrakcyjny o każdej porze dnia i nocy. W szczególności jednakże fenomen wizualny ujawniał się dopiero po zmroku, gdy rozświetlone sztucznym światłem wnętrze stanowiło kontrast dla otaczających pawilon ciemnych ścian budynków.

${ }^{30}$ K. Guttmejer, P. Świątek, Warszawski późny modernizm lat 60. Próba konserwatorskiego wartościowania, [w:] Wartościowanie w ochronie i konserwacji zabytków, red. B. Szmygin, Warszawa-Lublin 2012, s. 60.

31 M. Urbańska, op. cit., s. 57.

32 Ibidem.

33 J. Rajchert, Przeglad powojennych obiektów handlowych w Warszawie i ich dzień dzisiejszy, http://www.fundacja-hereditas.pl/portal/files/obiekty_handlowe_jrajchert.pdf.

34 Ibidem.

35 P. Giergoń, Pawilon handlowy. Chemia, 27.07.2010, http://www.sztuka.net/palio/html.run? Instance $=$ www.sztuka.net.pl\&_PageID $=853 \&$ newsId $=13448 \&$ cms $=$ newser\&_CheckSum $=$ 1567398524 (dostęp: 17.07.2017). 
Specjalnie zaprojektowane świecące neony, które notabene pojawiły się w Polsce w latach 60., wnosiły powiew współczesności. I chociaż wartość estetyczna podlega subiektywnej ocenie każdego człowieka (wszakże de gustibus non est disputandum), to ze względu na jego wartość historyczną, kulturową i zachowane w nim funkcjonalne rozwiązania pawilon powinien, w mojej opinii, zostać objęty ochroną - zapewniającą należyty stan zachowania i wartości. Zapobiegłoby to zarówno jego wyburzeniu, jak i utracie przestrzeni powietrznej zapewniającej dostęp do światła mieszkańcom sąsiednich gmachów. Zdaniem niektórych warto zainicjować dyskusję nad racjonalnością takich zmian.

Przytaczając bardziej aktualny przykład braku konsekwentnej ochrony, można wymienić niedawno wyburzony budynek „Emilii” (Warszawa), który pod koniec 2016 r. został wpisany do rejestru zabytków. Nastąpiło to jednak zdecydowanie zbyt późno, albowiem trzy miesiące po rozpoczęciu prac demontażu; ponadto nie wpisano obiektu w całości, gdyż bez pasażu i części parteru z tyłu. Sama decyzja o wpisaniu do rejestru nic by jednak nie zmieniła, ponieważ została uchylona w lutym 2017 r. przez generalnego konserwatora zabytków ${ }^{36}$. Chociaż więc sam pawilon zostanie planowo ,przeniesiony” kilkaset metrów dalej, zachowując przy tym niektóre elementy oryginalnej struktury, pozbawiony zostanie kontekstu otoczenia, integralnego środowiska oraz oryginalnych założeń pierwotnych.

Warto jeszcze wspomnieć, że z powodu braku precyzyjnych zapisów i dogłębnej wiedzy historycznej doszło do wyburzenia warszawskiej perełki architektury modernizmu ${ }^{37}$, a mianowicie budynku „Smyka”. Wpis do ewidencji w przypadku tego obiektu dotyczył jedynie oryginalnej części budynku, która ocalała po pożarze w 1975 r. Nie uwzględniał natomiast wszelkich rozwiązań wewnątrzprzestrzennych, które de facto pozostały bez zmian. Fakt ten stanowił wystarczający impuls pomagający deweloperowi w uzyskaniu pozwolenia na rozbiórkę elementów wtórnych, mimo że były częścią oryginalnego konceptu. W jego miejscu aktualnie powstaje nowoczesny biurowiec i choć z zewnątrz budynek ma nawiązywać do obiektu sprzed 70 lat, to wewnętrzna struktura zostanie całkowicie zmienio$\mathrm{na}^{38}$. Pierwotny budynek był związany z pewnymi podstawowymi założeniami modernizmu - syntezą funkcji wpływającej na formę. Wartym zastanowienia może być kwestia pozostawienia samej formy pozbawionej jednocześnie odpowiadającej jej funkcji.

36 T. Urzykowski, Emilia wyleciała z rejestru zabytków, 10.02.2017, http://wyborcza.pl/7,75248, 21356716,emilia-wyleciala-z-rejestru-zabytkow.html (dostęp: 18.07.2017).

37 G. Mika, Inni chronia my burzymy. Warszawski modernim $w$ ruinie, 11.06.2017, http://tvnwarszawa.tvn24.pl/informacje,news, inni-chronia-my-burzymy-warszawski-modernizm-w-ruinie,234173.html (dostęp: 18.07.2017).

38 Ibidem. 
Do listy wyburzonych ikon późnego modernizmu należą również m.in.:

- kino Skarpa projektu Zygmunta Stępiewskiego, idealnie wpasowujące się kiedyś w kontekst otoczenia, obecnie zastąpione apartamentowcem;

- kino WZ, po którym działka do dzisiaj pozostała niezagospodarowana;

— kino Praha, powstałe w latach 1948-1949 według projektu Jana Bogusławskiego oraz Józefa Jerzego Łowińskiego, było pierwszym w Warszawie powojennym kinem ${ }^{39}$. Socrealistyczny gmach został wyburzony przez inwestora tuż przed wpisaniem obiektu do rejestru zabytków, co stanowi kolejny dowód na niebywałą opieszałość służb konserwatorskich.

Podobny los spotkał Rotundę banku PKO, stanowiącą jeden z bardziej charakterystycznych punktów Warszawy — swoisty znak orientacyjny stolicy. Budynek ten stanowił ważną część tzw. Ściany Wschodniej, był zwieńczeniem pasażu Wiecha, co świadczyło o jego dużej wartości urbanistycznej. Zaprojektowany przez Jerzego Jakubowicza ${ }^{40}$, powstawał w latach 1960-1966. W 1979 r. budynek został w dużej mierze niefortunnie zniszczony z powodu wybuchu gazu, zachował się jednakże oryginalną konstrukcję. Pomimo wpisu Rotundy do rejestru zabytków stołeczny konserwator wydał decyzję zezwalającą na rozbiórkę budynku ${ }^{41}$.

Jako że Rotunda to tylko jeden $\mathrm{z}$ wielu obiektów tworzących wspomnianą wcześniej Ścianę Wschodnią, należy wspomnieć, że pozostałe z nich (Universal, Zodiak, czy Sezam) zostały zamienione w pasaż Wiecha i elewacje w punktowcach.

W przypadku Sezamu do wyburzenia doszło z powodu braku planu miejscowego zagospodarowania przestrzennego ${ }^{42}$. Zgodnie bowiem $\mathrm{z}$ ustawą o planowaniu i zagospodarowaniu przestrzennym (art. 39 ust. 3 pkt 2$)^{43} \mathrm{w}$ planie zagospodarowania przestrzennego województwa należy określić system obszarów chronionych, w tym dziedzictwo kulturowe i zabytki oraz dobra kultury współczesnej. Uwzględnienie w nim wszystkich wartościowych obiektów, których zachowanie leży w interesie państwa, nie doprowadziłoby do zniknięcia tak wielu ikon modernizmu.

Trzeba podkreślić, że miejsca reprezentacyjne w szczególności powinny być objęte ochroną i określonymi zasadami, tak aby nie dopuścić do przestrzennego nieładu — będącego dziś niestety plagą polskich miast. Przez „ład przestrzenny” należy rozumieć

39 P. Giergoń, Warszawa - Kino Praha, 2014, http://www.sztuka.net/palio/html.run?_Instance 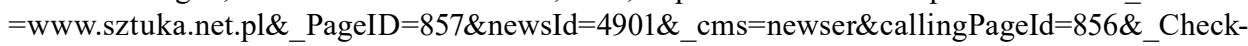 Sum=-2011183397 (dostęp: 18.07.2017).

40 M. Leśniakowska, Architektura w Warszawie, Warszawa 2005, s. 108.

41 T. Urzykowski, Rotunda. Konserwator wstrzymuje rozbiórkę, 16.03.2017, http://warszawa. wyborcza.pl/warszawa/7,54420,21506016, rotunda-konserwator-wstrzymuje-rozbiorke.html (dostęp: 19.07.2017).

42 G. Mika, op. cit.

43 Dz.U. z 2003 r. Nr 80, poz. 717. 
takie ukształtowanie przestrzeni, które tworzy harmonijną całość oraz uwzględnia w uporządkowanych relacjach wszelkie uwarunkowywania i wymagania funkcjonalne, społeczno-gospodarcze, środowiskowe, kulturowe oraz kompozycyjno-estetyczne ${ }^{44}$.

Ład przestrzenny uwzględnia również walory estetyczne, których pozbawione są teraz, w wyniku zaniedbań, liczne budynki, w szczególności późnomodernistyczne. Dlatego też wzbudzają one niechęć społeczeństwa żyjącego w ich bliskim otoczeniu.

Widniejące na budynkach obszerne reklamy nietrudno zauważyć nawet w Krakowie. Hotel Forum to przykład cennego obiektu z lat 90., który zachwycał surowością swej formy, czystością kompozycji oraz rozwiązaniami, jakie dawał w tamtych czasach tzw. żelbet. Zdaniem Krzysztofa Ingardena do zalet Hotelu Forum należy m.in.: kompozycja dwustrefowa, z prześwitem pomiędzy niskim parterem, bryła wpisująca się w geometrię terenu i powielająca linię brzegową bulwarów wiślanych oraz dynamika obiektu ${ }^{45}$. Obiekt ten, współgrając z otoczeniem, mógłby stanowić wizytówkę miasta, tymczasem zaniedbany i obleczony w reklamy nie świadczy dobrze o stanie polskiej powojennej architektury.

Doskonałą ilustrację okresu modernizmu stanowił również Hotel Cracovia, wybudowany przy reprezentacyjnej alei Trzech Wieszczów. To właśnie tam w latach 60. i 70. kwitło życie nocnego Krakowa. Niestety wszelkie próby odrestaurowania hotelu mają zostać podjęte dopiero teraz, po wielu latach protestów odnośnie do jego wyburzenia, przeprowadzania niezależnych ekspertyz i przekonywania opinii publicznej o słuszności ocalenia Cracovii ${ }^{46}$. I chociaż w tym wypadku wszystko wskazuje na to, że budynek ocaleje, cały proces prowadzący do takiego obrotu spraw wymagał nieadekwatnego nakładu sił i środków.

Niszczenie i proces destrukcji formy pozbawionej konserwacji jest naturalnym wynikiem upływu czasu. Nie powinno się więc dopuszczać do zaniżenia z tego powodu wartości architektonicznej, ponieważ to odpowiednia modernizacja jest drogą do osiągnięcia celu — zachowania dorobku kulturowego ludzkości.

Należy również pamiętać o ważnym kryterium autentyczności, którego pozbawione są wszelkie próby rekonstrukcji, usiłujące nieudolnie oddać ducha epoki. Sytuacja taka dotyczy Katowickiego Dworca Kolejowego, który zawiera kilka odtworzonych na kształt wcześniejszego dworca kielichów, przykrytych niestety przez galerię handlową ${ }^{47}$. Poprzedni dworzec, którego autorem był tercet architektów w składzie Wacław Kłyszewski, Jerzy Mokrzyński i Eugeniusz Wierzbicki,

44 Ibidem, art. 2 pkt 1.

45 K. Ingarden, Hotel Forum - relikt przeszłości, wyspa wolności czy urzędniczy pat?, 27.05.2015, http://wiadomosci.onet.pl/tylko-w-onecie/hotel-forum-relikt-przeszlosci-wyspa-wolnosci-czy-urzedniczy-pat/gcjf5m (dostęp: 20.07.2017).

46 F. Springer, Hotel Cracovia. Ocalony peerelowski bękart - miat być kolejna galeria handlowa, będzie muzeum, 2017, http://weekend.gazeta.pl/weekend/1,152121,21978131, hotel-cracovia-ocalony-peerelowski-bekart-mial-byc-kolejna.html (dostęp: 20.07.2017).

${ }^{47}$ M. Urbańska, op. cit., s. 57-58. 
stanowił znakomity przykład brutalizmu i jedną z ciekawszych konstrukcji kielichowych na świecie ${ }^{48}$. Powstawał w latach 1966-1972, kiedy połączenie dwóch elementów: estetyki brutalizmu i konstrukcji kielichowej uchodziło za coś wyjątkowo nowatorskiego. W efekcie budynek sprawiał wrażenie lekkości, zachowując jednocześnie bogatą fakturę nagiego betonu z widocznym szalunkiem desek. Niestety postępująca degeneracja budynku powodowała, że społeczeństwo odbierało go sceptycznie. Brud i masa umieszczonych na nim kolorowych reklam sprawiły, że obiekt powoli się zatracał.

Uznaje się, że dany przedmiot należy do kultury, o ile potrafi przetrwać w czasie $^{49}$. Profesor Tomasz Taczewski pisze, że „trwałość jest dokładnym przeciwieństwem użytkowości, która sprawia, że budynek stale, po odrobinie znika ze świata

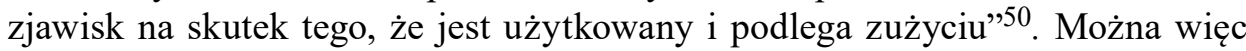
było przypuszczać, że budynek dworca, który nie przeszedł nigdy modernizacji, pozostawiony samowolnie, doczeka się smutnego zakończenia — także $\mathrm{w}$ jego przypadku na nic zdał się sprzeciw śląskich architektów. Zachowane w obiekcie dziedzictwo kulturowe stanowiło żywe „świadectwo minionej epoki”, dworzec był nie tylko ikoną architektury brutalistycznej, lecz także dowodem ciekawych rozwiązań architektonicznych, które rozwijały się w drugiej połowie XX w.

Z krajobrazu katowickiego śródmieścia zniknęły również Varieties: Centrum u Michalika i wieżowiec DOKP. Hotel Silesia wciąż natomiast czeka na realizację planów dotyczących jego wyburzenia, wydano bowiem na niego wyrok w postaci pozwolenia na rozbiórkę ${ }^{51}$. Urzeczywistnionego piękna modernizmu nie zobaczymy już nigdy także w Pałacu Ślubów, gdyż zastąpiony on został przez ogromny parking. Zaprojektowany przez profesora Mieczysława Króla ${ }^{52}$ „konstruktorski majstersztyk" składał się z dwóch osobnych części, które połączone były konstrukcją mostową ${ }^{53}$. Umożliwiał tym samym swobodne przejście pod budynkiem, sprawiał wrażenie lekkości i zwiększał obszar przestrzeni miejskiej. Zrealizowany był w myśl tzw. Karty Ateńskiej, która gwarantowała słońce, przestrzeń, zieleń dla każdego.

Peerelowska architektura Katowic została pozbawiona tak ważnych dzieł, które jeszcze nie tak dawno, w czasach swojej świetności, wzbudzały podziw i zachwyt. I choć podjęto działania w celu ochrony modernizmu — stworzono „Szlak mo-

48 Ibidem.

49 T. Taczewski, Smutek odchodzenia architektury, „Czasopismo Techniczne” 108, 2011, z. 4-A/1, s. 357.

50 Ibidem.

$51 \mathrm{pj}$, Hotel Silesia do wyburzenia. Urzad miasta wydat pozwolenie na prace rozbiórkowe, 18.04.2016, http://katowice.wyborcza.pl/katowice/1,35063,19936174,hotel-silesia-do-wyburzeniaurzad-miasta-wydal-pozwolenie-na.html (dostęp: 19.07.2017).

52 S. Adamczyk, Katowice - informator, Urząd Miasta w Katowicach, Katowice 1993, s. 26.

53 I. Sobczyk, Po Pałacu Ślubów może być pawilon, 1.03.2011, http://katowice.wyborcza.pl/ katowice/1,35019,9185486,Po_Palacu_Slubow_moze_byc_pawilon.html (dostęp: 19.07.2017). 
derny", to nie obejmował on ochroną ani dworca kolejowego, ani Pałacu Ślubów, które jeszcze wtedy stały. Niestety w tej kwestii powiedzenie less is more $e^{54}$ nie ma racji bytu.

\section{Podsumowanie}

Rozwój architektury niesie za sobą ryzyko utraty walorów estetycznych czy użytecznościowych. Konsekwencją upływającego czasu może być destrukcja pierwotnej formy lub też całkowite wyburzenie budynku. W celu wyeliminowania tego zjawiska należałoby podjąć jasno sprecyzowane działania — począwszy od sformułowania merytorycznych zasad oceny wartości. Ze względu na niedawne powstawanie architektury modernistycznej działania zapewniające jej ochronę nie są wyraźnie określone. Powszechne wyburzanie i zamiana budynków na nowe pozbawia świat wielu cennych obiektów, a więc i ram dla treści. Architektura przecież była, jest i będzie scenerią dla wszechobecnych treści historycznych.

Początkowa, właściwa ocena wartości jest niezbędna do podjęcia jakichkolwiek działań prowadzących do ochrony cennych obiektów. Jest tajemnicą poliszynela, że w wielu wypadkach wpisanie do rejestru zabytków odbyło się zdecydowanie za późno, co w konsekwencji nie pomogło w zmianie decyzji o wyburzeniu. W większości przypadków wszelkie próby konserwacji podejmowane są dopiero wtedy, gdy budynki przestają być użyteczne i funkcjonalne, a więc zaczynają stanowić już istotny problem. Wszelkie interwencje konserwatorskie post factum mogą być odbierane jedynie jako działania pozorne, które $\mathrm{w}$ istocie powinny przeciwdziałać niszczeniu i wyburzaniu obiektów. Bywa niestety tak, że czas, po którym dwudziestowieczny budynek doczekałby się uznania, jest dłuższy niż okres jego rentowności ${ }^{55}$.

W naszym interesie leży zachowywanie budynków, które dla przyszłych pokoleń będą już cennymi zabytkami. Wpis do rejestru zabytków może zapewnić im odpowiednią ochronę oraz powstrzymać inwestorów, którym często zależy jedynie na maksymalnym wykorzystaniu atrakcyjnych przestrzeni w samych centrach miast. Niedostateczna wiedza na temat wartości, jakie posiadają obiekty modernistyczne, oraz przypisywane im miano „źle urodzonych” nie wzbudza poparcia ze strony społeczeństwa dla ich ochrony.

Nie ulega również wątpliwości, że wszelkie zmiany powinny być przeprowadzane świadomie i z rozwagą, tak aby nie dopuścić do zwiększającego się przestrzennego nieładu. Zastępując tak cenne ikony modernizmu nowymi obiektami, trudno o dobrą zmianę.

54 Słynna maksyma odnosząca się do metody projektowania propagowanej przez Ludwiga Mies van der Rohe, który był również twórcą tego stwierdzenia.

55 K. Koziej, Ochrona dziedzictwa powojennego modernizmu, „Spotkania z Zabytkami” 2009, nr 7, s. 3 . 
I choć dostępnych jest wiele możliwości ich ochrony, codzienna praktyka przynosi wiele negatywnych zjawisk, ukazując bariery w sprawowaniu skutecznej polityki konserwatorskiej ${ }^{56}$. Jesteśmy świadkami kształtowania się historii naszego kraju, ważne jest zatem, by pamiętać o tym, co mówił John Ruskin w Siedmiu lampach architektury:

Możemy bez architektury żyć, odprawiać praktyki religijne, ale nie jesteśmy w stanie bez niej pamiętać. Jak zimna jest wszelka historia, jak pozbawione życia wszelkie wyobrażenia, w porównaniu do tego, co współcześnie narody piszą i niezmienne marmury niosą! Bez jak wielu stron niepewnych dokumentów często obywamy się dzięki kilku kamieniom leżącym jeden na drugim! $!^{57}$

Reasumując, powinniśmy dążyć do szerszej i skuteczniejszej ochrony wartościowych obiektów architektury późnego modernizmu, szczególnie zważywszy na fakt, że ustawowa definicja ,zabytku” nie ogranicza ochrony żadnymi ramami czasowym, a tym samym nie generuje prawnoformalnych barier w stosowaniu procedur ochrony tego dziedzictwa.

\section{Bibliografia}

Adamczyk S., Katowice - informator, Urząd Miasta w Katowicach, Katowice 1993.

Ciarkowski B., Kryterium autentyczności a wartościowanie zabytków architektury modernistycznej, Polski Komitet Narodowy ICOMOS, Muzeum Pałac w Wilanowie, Warszawa 2013.

Gawin M., Konferencja o ochronie dziedzictwa architektury i urbanistyki, 17.11.2016, http://mkidn. gov.pl/pages/posts/konferencja-o-ochronie-dziedzictwa-architektury-i-urbanistyki-6841.php.

Gawlicki M., Ocena wartości zasobu zabytkowego - cele, metody, praktyka, Polski Komitet Narodowy ICOMOS, Warszawa 2013.

Gawlicki M., Rejestr zabytków w praktyce ochrony konserwatorskiej, „Ochrona Zabytków” 2008, nr 2.

Giergoń P., Pawilon handlowy. Chemia, 27.07.2010, http://www.sztuka.net/palio/html.run?_Instan$\mathrm{ce}=$ www.sztuka.net.pl\&_PageID $=853 \&$ newsId $=13448 \&$ \&ms $=$ newser\&_CheckSum $=$ 1567398524.

Giergoń P., Warszawa — Kino Praha, 2014, http://www.sztuka.net/palio/html.run?_Instance=_www. sztuka.net.pl\&_PageID $=857 \&$ newsId $=4901 \&$ \& Sum $=-2011183397$.

Goldzamt E., Zagadnienie realizmu socjalistycznego w architekturze, [w:] O polska architekture socjalistyczna, Warszawa 1950.

Guttmejer K., Świątek P., Warszawski późny modernizm lat 60. Próba konserwatorskiego wartościowania, [w:] Wartościowanie w ochronie i konserwacji zabytków, red. B. Szmygin, Warszawa-Lublin 2012.

Ingarden K., Hotel Forum — relikt przeszłości, wyspa wolności czy urzędniczy pat?, 27.05.2015, http://wiadomosci.onet.pl/tylko-w-onecie/hotel-forum-relikt-przeszlosci-wyspa-wolnosci-czy-urzedniczy-pat/gcjf5m.

Kołodziejczyk Ł., Doktryna realizmu socjalistycznego, http://www.nh.pl/socrealizm.htm.

Koziej K., Ochrona dziedzictwa powojennego modernizmu, „Spotkania z Zabytkami” 2009, nr 7.

${ }^{56}$ M. Gawlicki, Ocena wartości zasobu zabytkowego..., s. 100.

57 T. Taczewski, op. cit., s. 357. 
Królikowski J.T., Modernizm warszawski po 1955. Zdobywanie i odzyskiwanie form. Referat, Katedra Sztuki Krajobrazu SGGW, Warszawa 2016.

Le Corbusier, W stronę architektury, Warszawa 2012.

Leśniakowska M., Architektura w Warszawie, Warszawa 2005.

Materiał ze strony „Mazowieckiego Wojewódzkiego Konserwatora Zabytków” dotyczący relacji z panelu o modernizmie, http://www.mwkz.pl/archiwum-aktualnosci-lista/1015-fotorelacja-z-panelu-o-modernizmie.

Mika G., Inni chronia, my burzymy. Warszawski modernizm w ruinie, 11.06.2017, http://tvnwarszawa. tvn24.pl/informacje,news, inni-chronia-my-burzymy-warszawski-modernizm-w-ruinie, 234173. html.

Pelczarski M., O ksztattowaniu konstrukcji dachu katowickiej hali Spodka. Rozważania z wywiadów z Profesorem Wactawem Zalewskim, „Architectus” 17, 2013, nr 2 (34).

pj, Hotel Silesia do wyburzenia. Urząd miasta wydat pozwolenie na prace rozbiórkowe, 18.04.2016, http://katowice.wyborcza.pl/katowice/1,35063,19936174,hotel-silesia-do-wyburzenia-urzad-miasta-wydal-pozwolenie-na.html.

Rajchert J., Przegląd powojennych obiektów handlowych w Warszawie i ich dzień dzisiejszy, http:// www.fundacja-hereditas.pl/portal/files/obiekty_handlowe_jrajchert.pdf.

Sobczyk I., Po Pałacu Ślubów może być pawilon, 1.03.2011, http://katowice.wyborcza.pl/katowice/1,35019,9185486,Po_Palacu_Slubow_moze_byc_pawilon.html.

Springer F., Hotel Cracovia. Ocalony peerelowski bękart — miat być kolejna galeria handlowa, będzie muzeum, 2017, http://weekend.gazeta.pl/weekend/1,152121,21978131, hotel-cracovia-ocalony-peerelowski-bekart-mial-byc-kolejna.html.

Szmygin B., Propozycje założeń do systemu wartościowania zabytków architektury — podmiot, przedmiot, status wartości, Polski Komitet Narodowy ICOMOS, Muzeum Pałac w Wilanowie, Warszawa 2013.

Taczewski T., Smutek odchodzenia architektury, „Czasopismo Techniczne” 108, 2011, z. 4-A/1.

Urbańska M., Polska architektura późnego modernizmu — kategorie stanu zachowania, syntetyczne studia przypadków i dylematy konserwacji, „Wiadomości Konserwatorskie — Journal of Heritage Conservation" 2016, nr 48.

Urzykowski T., Emilia wyleciała z rejestru zabytków, 10.02.2017, http://wyborcza.pl/7,75248, 21356716,emilia-wyleciala-z-rejestru-zabytkow.html.

Urzykowski T., Rotunda. Konserwator wstrzymuje rozbiórke, 16.03.2017, http://warszawa.wyborcza.pl/warszawa/7,54420,21506016,rotunda-konserwator-wstrzymuje-rozbiorke.html.

\section{Akty prawne}

Uchwała nr 1 RADY OCHRONY ZABYTKÓW przy Ministrze Kultury i Dziedzictwa Narodowego w sprawie ochrony dziedzictwa architektury i urbanistyki XX wieku w Polsce z dnia 29 kwietnia $2016 \mathrm{roku}, \mathrm{http}: / /$ konserwacja.pk.edu.pl/archXXpl/.

Ustawa z dnia 7 lipca 1994 r. — Prawo budowlane (Dz.U. z 1994 r. Nr 89, poz. 414).

Ustawa z dnia 27 marca 2003 r. o planowaniu i zagospodarowaniu przestrzennym (Dz.U. z 2003 r. $\mathrm{Nr} 80$, poz. 717 ).

Ustawa z dnia 23 lipca 2003 r. o ochronie zabytków i opiece nad zabytkami (Dz.U. z 2003 r. Nr 162, poz. 1568). 


\section{The disappearance of late modernism - shall the scope of the law's protection of monuments be broader?}

\section{Summary}

Architecture is associated with the risk of loss of aesthetics and usable qualities. The consequence of the elapsing time is the destruction of the original form or even the complete demolition of the whole building. In order to eliminate this dangers, a number of clearly defined actions need to be taken, starting from the establishment of specific valuation principles in order to protect the buildings as monuments. Because of the young age of modernist architecture, the actions to protect it are yet to be identified and properly defined. Frequent demolition and replacement of buildings into new ones deprives the world of numerous valuable objects, and thus - the framework for future. There is no doubt that architecture sets a scenery for ubiquitous historical content. Proper evaluation of buildings of all kinds is essential to initiate proper protection of the most precious ones. In many cases, the decision to enter some of objects in the Register of Historic Places was made too late, which in consequence did not successfully protected them from ultimate demolition. Part of the problem is that most of the maintenance attempts are made not until the buildings cease to be useful and functional anymore and only once they already become a significant problem to the public safety. Any kind of post factum conservation intervention from conservators and restorers can only be perceived as nothing more than illusive action, instead of effective counter reaction to destruction and demolition of buildings. Unfortunately, often the period in which a twentieth-century building would be acknowledged as monument is far longer than the period of its actual profitability. It therefore rests in our best interests to preserve the buildings that will yet become the valuable monuments for future generations. An entry in the register of monuments can provide adequate protection, as well as stop investors, who often want to occupy the most of attractive locations in the city centers. Inadequate knowledge about the values of late modernist objects and the ascribed of them names as "badly born" does not encourage their protection from the public. There is no doubt that any changes shall be made deliberately and with due care to prevent the ongoing issue of spatial chaos. Replacing valuable modernist icons with brand new buildings can raise doubts. Although there are many opportunities for their protection, daily practice is often ineffective and shows practical barriers to successful conservation public policy. As we witness the formation of our country's history, especially important to remember what John Ruskin has said in Seven lamps of architecture: "How cold is all history, how lifeless all imagery, compared to that which the living nation writes, and the uncorrupted marble bears! how many pages of doubtful record might we not often spare, for a few stones left one upon another!".

In conclusion, we should call for a broader and more effective protection of the priceless substance of modern architecture, especially given that the current statutory definition of "monument" does not limit the scope of protection and thus does not generate legal barriers to the use of heritage protection procedures. 